\title{
Small Lymphocytic Lymphoma with Unmutated Immunoglobulin Heavy Chain Variable-Region Gene
}

National Cancer Institute

\section{Source}

National Cancer Institute. Small Lymphocytic Lymphoma with Unmutated

Immunoglobulin Heavy Chain Variable-Region Gene. NCI Thesaurus. Code C37206.

Small lymphocytic lymphoma characterized by the absence of somatic hypermutation within the immunog lobulin heavy chain gene variable region of neoplastic clones. Patients have a significantly worse prognosis as compared to those with mutated immunog lobulin heavy chain gene variable region rearrang ements. 